\title{
Effect of basalt fibre on the mechanical properties of M70 grade high performance concrete
}

\author{
$V$ Ram Singh ${ }^{1}, V$ Srinivasa Reddy $^{2}, S$ Shrihari $^{3}, T$ Srikanth $^{4}$ \\ ${ }^{1}$ M.Tech (Structural Engineering), Department of Civil Engineering, GRIET, Hyderabad, India. \\ ${ }^{2}$ Professor of Civil Engineering, GRIET, Hyderabad, India. \\ ${ }^{3}$ Professor of Civil Engineering, VJIT, Hyderabad, India. \\ ${ }^{4}$ B.Tech Student, Department of Civil Engineering, GRIET, Hyderabad, India
}

\begin{abstract}
The presented work reveals the strength properties of $\mathrm{M} 70$ grade high performance basalt fibre reinforced concrete (BFRCC) containing $0.2 \%, 0.3 \%$ and $0.4 \%$ basalt fibre content by volume of concrete. $10 \%$ Silica fume is admixed for attaining higher strengths as preferred. Compressive, split-tensile and flexural strengths are evaluated. The BFRCC microstructure is found to be improved due to enrichment of interfacial transition zone with chopped basalt fibres. It was found that different fibre lengths require different dosages to yield maximum effect on the properties of concrete. Stress- strain responses of M70 grade BFRSCC yields improved ultimate strain and strain at peak load indicating its energy dissipation capacity at fracture.
\end{abstract}

\section{Introduction}

Development of microstructure of concrete plays a key role it's mechanical characteristics particularly the porosity of the concrete. Fibres in concrete is a very popular way a enhancing few properties of concrete. As many types of fibres are available in market, the choice of fibres have become a topic of debate even though each fibre will have its own specific effect on the properties of concrete. Use of naturally obtained basalt fibres in imparting greater delamination resistance, fracture energy absorption capability, toughness against fracture and the improved ductility endorsed to be used extensively in concrete. The popular problems associated with fibres such as segregation, dispersion, loss of shape, stiffness and cost involved are reduced by the use of basalt fibres. Research showed that not more than $0.5 \%$ of fibre volume fraction is required to be used. This low volume fibre content reduces shrinkage cracks especially in concrete elements with more exposed surface area such as pavements, slabs etc. In case of use in structural applications its content can be in the range of $1-2 \%$ to attain the strain hardening in concrete.

\section{M70 grade mix proportion}

In this study, mechanical properties of M70 grade high performance concrete is assessed based on strength tests, stress-strain under uniaxial loading of compression machine. Quantities needed for cubic metre of concrete are-

\footnotetext{
- Cement - $554.20 \mathrm{~kg} / \mathrm{m}^{3}$

- Fine Aggregate $659.15 \mathrm{~kg} / \mathrm{m}^{3}$

- Coarse Aggregate $1164.83 \mathrm{~kg} / \mathrm{m}^{3}$

- Silica Fume $55.42 \mathrm{~kg} / \mathrm{m}^{3}$

- Super plasticizer) $7.10 \mathrm{~kg} / \mathrm{m}^{3}$

- Water/binder ratio 0.28
}

\section{Workability}

The slump and inverted cone slump test are done of M70 grade BFRCC mixes are presented below.

Table 1. Slump in mm of M70 BFRCC mixes

\begin{tabular}{|c|c|c|c|c|c|}
\hline Type & Designation & Fibre length & Fibre volume & $\begin{array}{c}\text { Slump } \\
\text { in mm }\end{array}$ & $\begin{array}{c}\text { Inverted } \\
\text { Slump in sec }\end{array}$ \\
\hline $\begin{array}{c}\text { Normal } \\
\text { Concrete }\end{array}$ & $0 \%$ & 0 & 0 & 80 & 5.12 \\
\hline \multirow{2}{*}{$\begin{array}{c}\text { Basalt fibre } \\
\text { Concrete }\end{array}$} & $12 \mathrm{~mm}+0.2 \%$ & $12 \mathrm{~mm}$ & $0.20 \%$ & 156 & 4.98 \\
\cline { 2 - 6 } & $12 \mathrm{~mm}+0.3 \%$ & $12 \mathrm{~mm}$ & $0.30 \%$ & 122 & 4.44 \\
\hline
\end{tabular}




\begin{tabular}{|l|l|l|l|l|l|}
\hline \multirow{4}{*}{} & $36 \mathrm{~mm}+0.2 \%$ & $36 \mathrm{~mm}$ & $0.20 \%$ & 168 & 4.38 \\
\cline { 2 - 6 } & $36 \mathrm{~mm}+0.3 \%$ & $36 \mathrm{~mm}$ & $0.30 \%$ & 176 & 4.01 \\
\cline { 2 - 6 } & $36 \mathrm{~mm}+0.4 \%$ & $36 \mathrm{~mm}$ & $0.40 \%$ & 160 & 3.77 \\
\cline { 2 - 6 } & $50 \mathrm{~mm}+0.2 \%$ & $50 \mathrm{~mm}$ & $0.20 \%$ & 176 & 3.98 \\
\cline { 2 - 6 } & $50 \mathrm{~mm}+0.3 \%$ & $50 \mathrm{~mm}$ & $0.30 \%$ & 180 & 3.56 \\
\cline { 2 - 6 } & $50 \mathrm{~mm}+0.4 \%$ & $50 \mathrm{~mm}$ & $0.40 \%$ & 112 & 3.22 \\
\hline
\end{tabular}

\section{Strength investigations}

The table 2 presents compressive strengths of M70 grade BFRSCC mixes. Table 3 shows split-tensile strengths of M70 grade BFRSCC mixes. Table 4 gives flexural strength values of M70 grade BFRSCC mixes.

Table 2. Compressive strengths of M70 BFRCC mixes

\begin{tabular}{|c|c|c|c|c|}
\hline \multirow{3}{*}{ Type } & Designation & Fibre length & Fibre volume & $\begin{array}{c}\text { Compressive } \\
\text { Strength } \\
\text { in MPa }\end{array}$ \\
\hline \multirow{3}{*}{$\begin{array}{c}\text { Normal } \\
\text { Concrete }\end{array}$} & $0 \%$ & 0 & 0 & 78.24 \\
\hline \multirow{5}{*}{$\begin{array}{c}\text { Basalt fibre } \\
\text { Concrete }\end{array}$} & $12 \mathrm{~mm}+0.2 \%$ & $12 \mathrm{~mm}$ & $0.20 \%$ & 80.38 \\
\cline { 2 - 5 } & $12 \mathrm{~mm}+0.3 \%$ & $12 \mathrm{~mm}$ & $0.30 \%$ & 82.48 \\
\cline { 2 - 5 } & $12 \mathrm{~mm}+0.4 \%$ & $12 \mathrm{~mm}$ & $0.40 \%$ & 86.30 \\
\cline { 2 - 5 } & $36 \mathrm{~mm}+0.2 \%$ & $36 \mathrm{~mm}$ & $0.20 \%$ & 83.14 \\
\cline { 2 - 5 } & $36 \mathrm{~mm}+0.3 \%$ & $36 \mathrm{~mm}$ & $0.30 \%$ & 80.46 \\
\cline { 2 - 5 } & $36 \mathrm{~mm}+0.4 \%$ & $36 \mathrm{~mm}$ & $0.40 \%$ & 88.78 \\
\cline { 2 - 5 } & $50 \mathrm{~mm}+0.2 \%$ & $50 \mathrm{~mm}$ & $0.20 \%$ & 87.10 \\
\hline
\end{tabular}

Table 3. Split tensile strength of M70 BFRCC mixes

\begin{tabular}{|c|c|c|c|c|}
\hline \multirow{2}{*}{ Type } & Designation & Fibre length & Fibre volume & $\begin{array}{c}\text { Split-tensile } \\
\text { Strength } \\
\text { in MPa }\end{array}$ \\
\hline \multirow{3}{*}{$\begin{array}{c}\text { Normal } \\
\text { Concrete }\end{array}$} & $0 \%$ & 0 & 0 & 5.92 \\
\hline \multirow{5}{*}{ Basalt fibre Concrete } & $12 \mathrm{~mm}+0.2 \%$ & $12 \mathrm{~mm}$ & $0.20 \%$ & 6.22 \\
\cline { 2 - 5 } & $12 \mathrm{~mm}+0.3 \%$ & $12 \mathrm{~mm}$ & $0.30 \%$ & 6.58 \\
\cline { 2 - 5 } & $12 \mathrm{~mm}+0.4 \%$ & $12 \mathrm{~mm}$ & $0.40 \%$ & 7.56 \\
\cline { 2 - 5 } & $36 \mathrm{~mm}+0.2 \%$ & $36 \mathrm{~mm}$ & $0.20 \%$ & 8.76 \\
\cline { 2 - 5 } & $36 \mathrm{~mm}+0.3 \%$ & $36 \mathrm{~mm}$ & $0.30 \%$ & 9.04 \\
\cline { 2 - 5 } & $56 \mathrm{~mm}+0.4 \%$ & $36 \mathrm{~mm}$ & $0.40 \%$ & 7.98 \\
\cline { 2 - 5 } & $50 \mathrm{~mm}+0.3 \%$ & $50 \mathrm{~mm}$ & $0.20 \%$ & 8.42 \\
\cline { 2 - 5 } & $50 \mathrm{~mm}+0.4 \%$ & $50 \mathrm{~mm}$ & $0.30 \%$ & 7.96 \\
\hline
\end{tabular}

Table 4. Modulus of rupture of M70 BFRCC mixes

\begin{tabular}{|c|c|c|c|c|}
\hline Type & Designation & Fibre length & Fibre volume & $\begin{array}{c}\text { Modulus of } \\
\text { rupture } \\
\text { MPa }\end{array}$ \\
\hline $\begin{array}{c}\text { Normal } \\
\text { Concrete }\end{array}$ & $0 \%$ & 0 & 0 & 7.24 \\
\hline \multirow{2}{*}{$\begin{array}{c}\text { Basalt fibre } \\
\text { Concrete }\end{array}$} & $12 \mathrm{~mm}+0.2 \%$ & $12 \mathrm{~mm}$ & $0.20 \%$ & 7.78 \\
\cline { 2 - 5 } & $12 \mathrm{~mm}+0.3 \%$ & $12 \mathrm{~mm}$ & $0.30 \%$ & 9.12 \\
\hline
\end{tabular}




\begin{tabular}{|l|c|c|c|c|}
\hline \multirow{4}{*}{} & $36 \mathrm{~mm}+0.2 \%$ & $36 \mathrm{~mm}$ & $0.20 \%$ & 8.26 \\
\cline { 2 - 4 } & $36 \mathrm{~mm}+0.3 \%$ & $36 \mathrm{~mm}$ & $0.30 \%$ & 10.68 \\
\cline { 2 - 5 } & $36 \mathrm{~mm}+0.4 \%$ & $36 \mathrm{~mm}$ & $0.40 \%$ & 10.9 \\
\cline { 2 - 5 } & $50 \mathrm{~mm}+0.2 \%$ & $50 \mathrm{~mm}$ & $0.20 \%$ & 10.44 \\
\cline { 2 - 5 } & $50 \mathrm{~mm}+0.3 \%$ & $50 \mathrm{~mm}$ & $0.30 \%$ & 11.34 \\
\cline { 2 - 5 } & $50 \mathrm{~mm}+0.4 \%$ & $50 \mathrm{~mm}$ & $0.40 \%$ & 10.54 \\
\hline
\end{tabular}

\section{Stress-strain investigation on BFRCC mixes}

The investigations to assess stress strain values of various length and dose combinations of M30 BFRCC mixes. Cylinders are uniaxially compressed under strain controlled rate of loading.

Table 5. Stress strain values of various length and dose combinations of M70 grade BFRCC mixes

\begin{tabular}{|c|c|c|c|c|c|c|c|}
\hline \multicolumn{2}{|c|}{$0 \%$ fibre } & \multicolumn{2}{|c|}{$\begin{array}{c}12 \mathrm{~mm} \text { length }+0.4 \% \\
\text { fibre } \\
\text { M70 BFRCC }\end{array}$} & \multicolumn{2}{|c|}{$\begin{array}{c}36 \mathrm{~mm} \text { length }+0.3 \% \\
\text { fibre } \\
\text { M70 BFRCC }\end{array}$} & \multicolumn{2}{|c|}{$\begin{array}{c}50 \mathrm{~mm} \text { length }+0.2 \% \\
\text { fibre } \\
\text { M70 BFRCC }\end{array}$} \\
\hline Strain & Stress $(\mathrm{MPa})$ & Strain & Stress(MPa) & Strain & Stress $(\mathrm{MPa})$ & Strain & Stress $(\mathrm{MPa})$ \\
\hline 0 & 0 & 0 & 0 & 0 & 0 & 0 & 0 \\
\hline 0.0002963 & 5.240175 & 0.0000373 & 1.167116 & 0.000043 & 0.393013 & 0.000044 & 2.155172 \\
\hline 0.0004444 & 9.432314 & 0.0002422 & 7.39229 & 0.000302 & 5.502183 & 0.000177 & 9.051724 \\
\hline 0.0006667 & 13.9738 & 0.0004286 & 12.45202 & 0.000732 & 14.14847 & 0.000486 & 15.94828 \\
\hline 0.0008889 & 17.81659 & 0.0006894 & 18.68221 & 0.001076 & 21.22271 & 0.000817 & 22.84483 \\
\hline 0.0011296 & 23.40611 & 0.0010062 & 24.52949 & 0.001528 & 30.65502 & 0.001126 & 33.62069 \\
\hline 0.0012593 & 25.15284 & 0.0014534 & 34.26772 & 0.001742 & 39.30131 & 0.001435 & 40.94828 \\
\hline 0.0016667 & 32.48908 & 0.0018447 & 42.44923 & 0.002043 & 46.37555 & 0.001811 & 49.13793 \\
\hline 0.0020926 & 39.12664 & 0.0021988 & 50.6274 & 0.002474 & 53.05677 & 0.002142 & 56.89655 \\
\hline 0.0022963 & 43.66812 & 0.0026273 & 59.20019 & 0.002819 & 57.37991 & 0.002407 & 60.34483 \\
\hline 0.0025556 & 48.9083 & 0.0029627 & 65.04914 & 0.00312 & 64.84716 & 0.002672 & 67.24138 \\
\hline 0.0027037 & 52.0524 & 0.0031304 & 67.39173 & 0.003616 & 71.9214 & 0.002959 & 75.86207 \\
\hline 0.0029444 & 56.94323 & 0.0034472 & 71.2994 & 0.003941 & 74.27948 & 0.00329 & 78.44828 \\
\hline 0.0031481 & 62.18341 & 0.0037453 & 74.04162 & 0.0042 & 77.42358 & 0.003621 & 80.60345 \\
\hline 0.003537 & 64.27948 & 0.0040621 & 78.3372 & 0.00448 & 80.56769 & 0.003997 & 81.46552 \\
\hline 0.0037407 & 64.97817 & 0.0042298 & 81.45564 & 0.004674 & 83.31878 & 0.004328 & 83.18966 \\
\hline 0.0040741 & 70.21834 & 0.004528 & 81.4824 & 0.005021 & 84.49782 & 0.004438 & 83.62069 \\
\hline 0.0043333 & 66.37555 & 0.0048261 & 80.7333 & 0.005454 & 84.89083 & 0.004858 & 87.06897 \\
\hline 0.0044074 & 62.53275 & 0.0050497 & 77.64998 & 0.00576 & 77.81659 & 0.005233 & 87.06897 \\
\hline 0.0046111 & 55.8952 & 0.0051429 & 72.61533 & 0.00587 & 71.52838 & 0.005521 & 87.06897 \\
\hline 0.0047407 & 49.25764 & 0.0051988 & 67.18941 & 0.005981 & 64.06114 & 0.005763 & 81.89655 \\
\hline & & 0.0052547 & 63.70311 & & & 0.005918 & 75.43103 \\
\hline & & & & & & 0.006006 & 67.24138 \\
\hline
\end{tabular}

If the patterns in which cracks are formed, for smaller fibre lengths vertical cracks are formed due to localized fracture whereas in higher aspect ratios the cracks are diagonally formed. In higher aspect ratio the distribution of stresses are evenly throughout the concrete matrix. Stresses undergone by $50 \mathrm{~mm}$ fibre length $+0.2 \%$ fibre dose BFRCC mix is found to be high when compared with the stress-strain responses of the other BFRCC mixes with fibre less than $50 \mathrm{~mm}$.

Table 6. Strains at peak and ultimate stresses

\begin{tabular}{|c|c|c|c|c|}
\hline \multirow{2}{*}{$\begin{array}{c}\text { M30 grade BFRCC } \\
\text { Type }\end{array}$} & \multicolumn{4}{|c|}{ Stress strain characteristics } \\
\cline { 2 - 5 } & Stress at Ultimate load & Corresponding strain & Ultimate & Strain ratio \\
& $(\mathrm{MPa})$ & at Ultimate load & Strain & $\varepsilon_{2 /} \varepsilon_{1}$ \\
\hline
\end{tabular}




\begin{tabular}{|c|c|c|c|c|}
\hline & & & & \\
\hline 0\% fibre & 70.22 & 0.0040741 & 0.0047407 & 1.16 \\
\hline $12 \mathrm{~mm}$ length $+0.4 \%$ fibre & 81.48 & 0.004528 & 0.0052547 & 1.16 \\
\hline $36 \mathrm{~mm}$ length $+0.3 \%$ fibre & 84.89 & 0.005454 & 0.005981 & 1.10 \\
\hline $50 \mathrm{~mm}$ length $+0.2 \%$ fibre & 87.06 & 0.005521 & 0.006006 & 1.09 \\
\hline
\end{tabular}

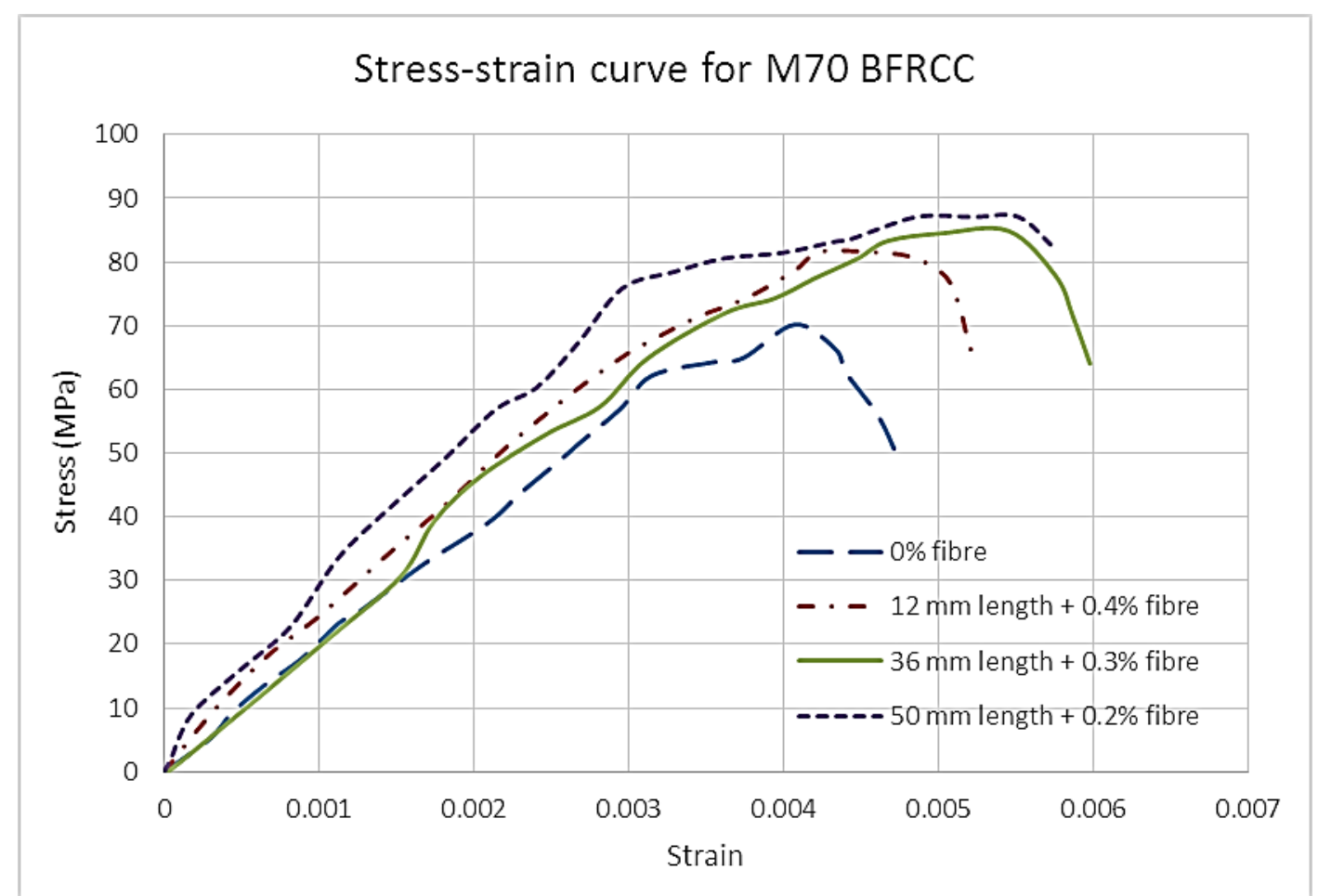

Fig. 1. Stress-strain curve for M70 grade BFRCC

In normal concrete the stress is found to be attaining peak value for a strain value of 0.002 and afterwards stress decreases which indicated by a dipping curve till ultimate crushing strain is reached. In BFRCC mixes the strain at peak value of stress is more than 0.002 showing its ability to endure more strain without normal failure. As the stresses increases, the pre-peak curve becomes nonlinear and the post-peak curve which indicates strain capability also decreases. The curve beyond post peak is directly related to the fibre length and fibre dose and it is virtually steep as arising curve for 12 and $36 \mathrm{~mm}$ fibre lengths and is further progressively inclined for the $50 \mathrm{~mm}$ fibre lengths. Dosage required decreases as fibre length increases. Table 7 conceals the Elastic Modulus (E) and Toughness Modulus of M70 grade BFRSCC mixes

Table 7. Elastic Modulus (E) and toughness

\begin{tabular}{|c|c|c|}
\hline \multirow{2}{*}{$\begin{array}{c}\text { M30 grade BFRCC } \\
\text { Type }\end{array}$} & \multicolumn{2}{|c|}{ Elastic Modulus (E) and Toughness Modulus } \\
\cline { 2 - 3 } & $\begin{array}{c}\text { Elastic Modulus (E) } \\
\text { GPa }\end{array}$ & $\begin{array}{c}\text { Toughness Modulus } \\
\text { MPa }\end{array}$ \\
\hline $0 \%$ fibre & 42.19 & 0.086 \\
\hline $12 \mathrm{~mm}$ length $+0.4 \%$ fibre & 44.87 & 0.153 \\
\hline $36 \mathrm{~mm}$ length $+0.3 \%$ fibre & 47.81 & 0.166 \\
\hline $50 \mathrm{~mm}$ length $+0.2 \%$ fibre & 49.38 & 0.184 \\
\hline
\end{tabular}




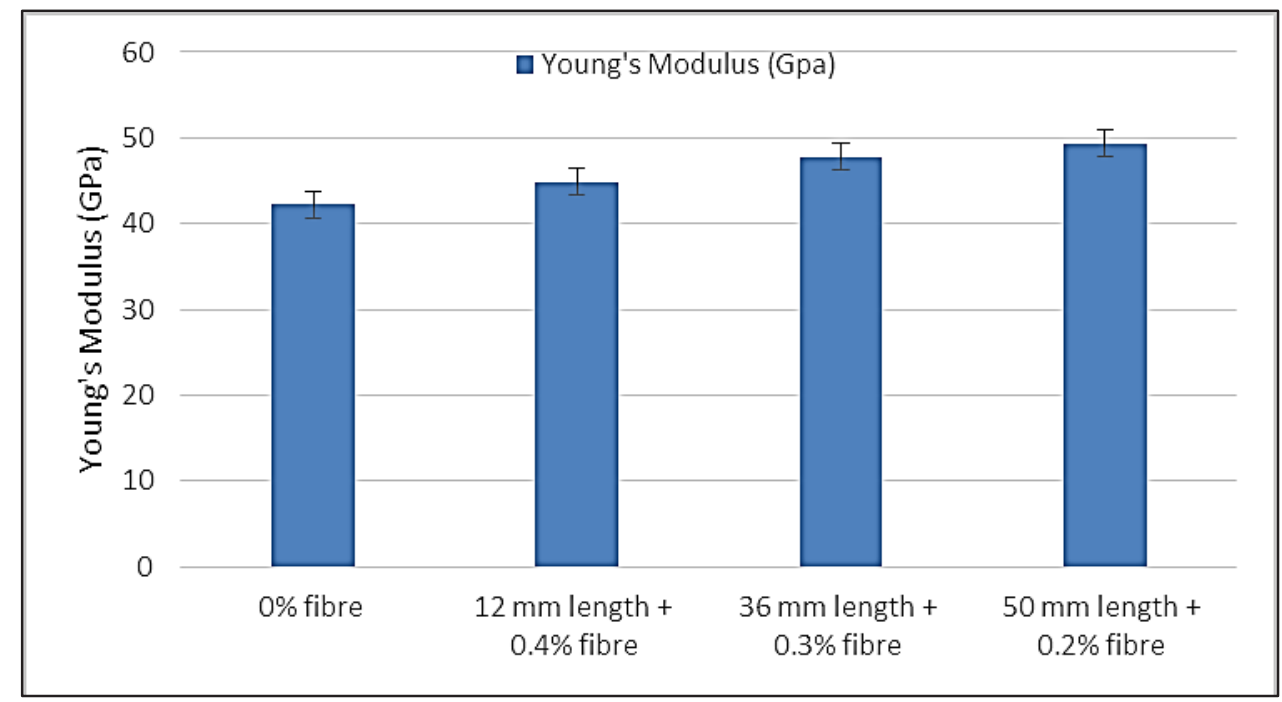

Fig. 2. Modulus of Elasticity for M70 grade BFRCC

\section{Conclusions}

From the interpretations from the stress-strain curves, the resulting conclusions are presented below:

1. For fibre length of $50 \mathrm{~mm}$ and measure of $0.2 \%$ fibre volume of the concrete, the compressive and flexural strengths achieved are maximum but the split tensile strength is found to be more for fibre length of $36 \mathrm{~mm}$ and dosage of $0.3 \%$ fibre volume of the concrete.

2. The increase in split-tensile and flexural strength of basalt fibred concrete is significant than the compressive strength.

3. The best length of fibre for basalt fibre concrete is $50 \mathrm{~mm}$ and dosage is $0.2 \%$ by volume fraction.

4. M70 grade BFRCC mixes has demonstrated greater stress values for the comparable strains as length of fibres and dose increases.

5. The strain at ultimate stress is slightly more, and the slope of the descending part is sharper due to the decrease in the extent of internal micro cracking in bacteria induced concrete

6. Ares underneath stress-strain plot gives the energy relieving ability of the concrete. BFRCC mixes has high energy dissipation ability due to fibres. As length of fibre increases impact resistance also increases similarly as dose increases the impact energy dissipation increases in BFRCC mixes due to fibres will control the cracks length and width formation by disintegrating distortion energy.

7. Improvement in moduli of toughness value in BFRCC mixes imply its developed resistance to impact. It is witnessed that Elastic modulus (E) is moderately increased for all BFRCC mixes as fibre lengths and added volume fraction increases indicating its better performance.

\section{References}

1. Jalasutram, S., Sahoo, D. R., \&amp; Matsagar, V. (2016). Experimental investigation on mechanical properties of basalt fibre-reinforced concrete. Structura Concrete. doi:10.1002/suco.201600216C.

2. Jiang, K. Fan, F. Wu, D. Chen, Experimental study on the mechanical properties and microstructure of chopped basalt fibre reinforced concrete, Mater. Des. 58 (2014) 187-193.

3. Tummala Suresh Kumar, Kosaraju Satyanarayana, Materials Today: Proceeding, 26 (2), 3228-3233, (2020).

4. Branston, John, et al. "Mechanical behaviour of basalt fibre reinforced concrete." Construction and Building Materials 124 (2016): 878-886.

5. Tumadhir, M. "Thermal and mechanical properties of basalt fibre reinforced concrete." International Journal of Civil and Environmental Engineering 7, no. 4 (2013): 334-337.

6. Fan, Fei Lin, et al. "Experimental study on impactmechanics properties of basalt fibre reinforced concrete." Advanced Materials Research. Vol. 168. Trans Tech Publications Ltd, 2011. 